\title{
METHODICAL APPROACHES OF THE INTERCULTURAL COMPETENCE FORMATION OF FUTURE ECONOMISTS
}

\author{
Oksana V. Polyakova ${ }^{1}$ \\ Alina F. Nigmatullina ${ }^{2}$ \\ Margarita A. Mihailova ${ }^{3}$
}

\begin{abstract}
The paper represents the results of conducted experiments on the formation of intercultural competence among undergraduate economics students of Kazan Federal University (Russia). Aimed at describing the advantages of the intercultural competence formation approach, the article focuses on the evidence of competence-based approach's effectiveness in the formation of intercultural competence. The business games, projects, discussions, brainstorming, and simulation games were used as the methods of the formation of the intercultural competence. Both a linguistic and a cultural components have become increasingly important in the personality of an international level modern economist. In addition to knowledge in the professional field, future economist
\end{abstract}

needs to possess cultural, sociocultural knowledge and skills that allow him to adequately represent himself in situations of intercultural communication. This problem is widely discussed these days due to the active growth of theoretical and practical interest in issues of intercultural communication. The introduction of a two-level education system (bachelor's and master's degrees) in Russia entails a considerable number of changes, including creating courses related to the world economy in a foreign language. These programs must be compiled in accordance with the federal state standards of the generation $3+$ and must be implemented in the professional training of future economists at the Institute of Management, Economics and Finance of the KFU. Hence, there is a need to increase the level of intercultural

\footnotetext{
${ }^{1}$ Kazan Federal University. e-mail: gerry-93@inbox.ru.phone:+79872897302

${ }^{2}$ Kazan Federal University. e-mail: gerry-93@inbox.ru. phone:+79872897302

${ }^{3}$ Kazan Federal University. e-mail: gerry-93@inbox.ru. phone:+79872897302.
} 
competence of future specialists in the economy field and the need for pedagogical theory and practice in the formation of intercultural competence of students in the process of teaching a foreign language at a university.

Keywords: intercultural competence, competence, future economists, intercultural communication, foreign language, higher education, English language learning.

\section{Introduction}

Rising interest in the problems of intercultural communication in the modern world is obvious. It is connected with the processes of business integration, the information space expansion and the development of Internet technologies as well as with the business advancement and enriching personal contacts. Russia enters the world community and this necessitates new approaches in teaching foreign language to students of non-linguistic departments. For them a foreign language is the main tool for future professional activities [Chiu Chi-Yue, 2013]. Expansion of international cooperation requires a modern economist to know a foreign language on a fundamentally new level which should include acquiring intercultural competence. The problem of future economists' intercultural competence formation and evaluation is connected with the process of intercultural communication and requires not only a high level of professional and communicative competence, but also the ability for independent reflexive mastering of their own norms of behavior for intercultural communication.

\section{Formation of intercultural competence among future economists}

The analysis of the existing university practice in the field of professionally directed teaching of foreign languages shows that in the process of intercultural communication even those specialists who are fluent in a foreign language are still experiencing great difficulties in understanding the meaning of foreign professional communication. This happens due to ignorance of the norms and cultural and specific values of another country, the lack of personal behavioral qualities 


\section{Periódico do Núcleo de Estudos e Pesquisas sobre Gênero e Direito \\ Centro de Ciências Jurídicas - Universidade Federal da Paraíba \\ V. 8 - No 04 - Ano 2019 - Special Edition}

ISSN | 2179-7137 | http://periodicos.ufpb.br/ojs2/index.php/ged/index

necessary for effective communication in an intercultural environment. Therefore, the search for ways to organize the formation of intercultural professional competence is one of the topical areas of pedagogical research aimed at optimizing education in nonlinguistic department. There is a real need to determine appropriate conditions for the formation of intercultural competence among students of economic specialties of universities in accordance with the requirements of the Federal State Educational Standards of Higher Professional Education [Federal state educational standard of higher professional education for the training, 2015].

According to this document language and verbal knowledge of an economist are the following: he must accurately recognize and use professionally meaningful vocabulary blocks of economic and management terminology. He must observe certain speech etiquette for expressing various communicative intentions. The latter may include greeting or farewell, acquaintance, self-presentation, establishing contact, asking questions, searching for necessary information, expressing a request, indicating, completing a conversation. The logical and compositional skills in solving problems of foreign language communication of the economist include the ability of structuring the sentences correctly, taking into account relationships and sequence patterns, also style and the register of professional communication. It is worthwhile to highlight the ability to compose a professionally significant message or statement, in particular a report on the company's work, the situation of the meeting at the airport / railway station, the presentation of the product, the advertisement of the vacancy, the interview. The student should be able to produce typical samples of professional and business communication, adequately transmit models of speech behavior and ways of communicating with correspondence to the business culture. It is also necessary to have intercultural awareness and ideas about the ways to reflect values of the business. The student, who is mastering how social factors and relations between business partners influence the choice of language units, can increase the success of professional and business 


\section{Periódico do Núcleo de Estudos e Pesquisas sobre Gênero e Direito \\ Centro de Ciências Jurídicas - Universidade Federal da Paraíba \\ V. 8 - No 04 - Ano 2019 - Special Edition}

ISSN | 2179-7137 | http://periodicos.ufpb.br/ojs2/index.php/ged/index

communication in general [Yarmakeev

Iskander E, 2016]. Foreign language communicative competence of the student performs as a general, elusive in learning short time aim. It implies such language proficiency that approaches to the language of native speakers by its linguistic parameters; therefore, oral and written forms of training should differ in correctness, disengagement, stylistic adequacy, accordance to the situation of communication. [Fahrutdinova R.A., 2014]

\section{Methods}

There are different methods that can qualify as productive educational activities for students. We chose the ones that allow successfully forming the intercultural competence of students in the process of teaching a professionally oriented foreign language course.

For instance, business game can simulate various speech situations. This provides conditions for the integrated application of existing knowledge, improving the foreign language skills they already have as well as a more complete mastery of a foreign language as a tool of formation of intercultural competence among economics students

[Deardorff D.K., 2006].

Project method is based on recreating a social interaction in a small group during the educational process. It creates conditions that contribute not only to increasing the amount of knowledge of foreign language among students in training, but also has an impact on their mobility, creativity, autonomy [Gorelova J.N., 2014] As a student solves creative tasks for the implementation of the project he also acquires knowledge. With the activities done on the way to perform a successful project presentation, students use a variety of forms and methods of work, which indicates the flexibility of thinking, the development of creativity, independence, and intellectual activity of future specialists in the sphere of economy. In a professionally oriented foreign language course, design technology can be effectively used at all stages of training, but its role at the stage of mastering the language in the field of a particular specialty is quite significant. A complicated ethnic composition of Russia's population and its multiconfessional nature cause the educational system to fulfill the 


\section{Periódico do Núcleo de Estudos e Pesquisas sobre Gênero e Direito \\ Centro de Ciências Jurídicas - Universidade Federal da Paraíba \\ V. 8 - No 04 - Ano 2019 - Special Edition}

ISSN | 2179-7137 | http://periodicos.ufpb.br/ojs2/index.php/ged/index

following functions: educational: characteristics and the advantages of the providing the universal education to the case-study technology in the country's population regardless of ethnic origin and religion; ethno-cultural function: disseminating and developing ethnic cultures and languages; consolidating function: integrating the ethnically heterogeneous society into a united supranational community - a political nation - with a common system of values. [L.Salekhova, K.Grigorieva, 2017]. The project work is interdisciplinary which can also influence intercultural competence acquisition during English language learning. And the role of the teacher significantly changes. He becomes the facilitator who watches but doesn't interfere unless it's really necessary [Kramsch C., 2004].

Case-study is a method of active learning which has become popular recently. It imitates and sets up real life situations. The method relies on the organization of discussions on the specific issues. The students are given various tasks connected with the world of business; most of them have issues or problematic areas so the trainees are expected to offer solutions and creative ideas for improving the situations. The development of personal characteristics of students are ensuring their readiness for professional activity and, consequently, a successful professional adaptation. [Albina R. Abdrafikova, 2015]. The case method can be even more successful in combination with other methods of teaching foreign languages such as system analysis, modeling, problem method, discussion, «brainstorming» and game methods) The main idea of the "brainstorming method" is to organize groups working together on proposing as many ideas for solving some matter in the most creative and untraditional ways as possible. This method demonstrates advantages of cooperation and that many solutions could be found if the group is working together effectively.

These methods give students the opportunity to:

1. Directly participate in team work because the methods under discussion involve a high number of students in the learning process. It is practically impossible to find a student who does not take an active participation in the work; 


\section{Develop social and personal} skills, learn to make decisions together and respect different points of view, thereby revealing leadership qualities. In addition, it also touches upon developing critical thinking and creativity;

3. To learn how to organize their speeches, formulate the main points with illustrative examples in a graphic or collisional form. They start prioritizing, highlighting the main ideas from the less relevant parts. Students also practice creating logical chains and attracting the attention of the audience, which contributes to the development of oratory skills and the ability to represent their own opinions and creative ideas.

To sum up, these methods of teaching have great pedagogical potential, which is aimed at forming intercultural competence of future economists in the process of learning English.

\section{Conclusions}

The scientific novelty and theoretical significance of the research are:

- The specification of the term "intercultural competence" as an integrated systematized phenomenon of a humanistic worldview, including a high culture of interpersonal communication and a generally developed cultural level.

- Defining content of the main educational programs of the "Foreign Language" discipline and stating their place in the formation of the intercultural competence of students - future economists in the educational space of the university;

- Creating the model of formation of intercultural competence of the undergraduate student in the process of teaching a foreign language is developed;

- Identifying methodical means (content, forms, methods, conditions) for ensuring the process of forming the intercultural competence of undergraduate students in accordance with the requirements of new educational standards have been determined and their effectiveness has been experimentally proven.

- Research materials can be used by university teachers and methodologists in the system of advanced training and retraining of educators to improve the educational process of teaching a foreign language, 
in general, and the formation of intercultural competence, in particular.

\section{Discussion}

The research was aimed at measuring the awareness of intercultural competence at the beginning of the English language course and at the end after performing certain tasks set by us (the duration of it for students majoring in economics is 2 years which equals to four semesters). Experimental work on the formation of intercultural competence of students by means of English language teaching has been carried out on the basis of Kazan Federal University, Institute of Management, Economics and Finance. The survey was held among 50 second-term first year undergraduate students of the Management department. The group was exposed to English language classes with the use of different methods such as case-study, project method, and "brainstorming". The methods we used helped students to enrich their vocabulary, use self-correction through grammar, work on problem-solving and teamwork as well as train in presenting themselves and defending their points of view.
The questionnaire we created was conducted among 50 respondents. It has revealed that more than a half of the students in the target groups are aware of intercultural competence phenomenon [Sinicrope C., 2012]. They came across it, know the field it's used in. However they experience difficulties in giving the proper definition to the term "intercultural competence". Mostly they confuse it with linguistic competence. By the end of the experiment we increased the number of students who are able to define the term from $41 \%$ to $75 \%$.

Due to this fact it was quite unexpected that at the beginning of the experiment more that $74 \%$ stated the importance of intercultural competence in the process of learning English and becoming successful managers. The majority of the students highlight the importance of intercultural competence development in the ESL classroom. They see necessity in its further formation and think that it's a key issue in developing business connections. The results of this question were high at both beginning and the end of the research. As we questioned the weakest parts in the process of intercultural communication that students can mention we found out that: 
$43 \%$ cannot carry a successful oral conversation with native speakers, $26 \%$ said that they have difficulties in using idioms and special business vocabulary that is common in everyday speech, movies and in interviews they watched online. $6 \%$ of the students who have taken the survey confessed that they are unfamiliar with the values and proper ways of behaving during different speech situations. They were not sure of the proper greetings or how to behave during the job interview in a multinational company. By using roleplays and other simulation activities we had the number of unconfident in the process of communication students decreased from $43 \%$ to $29 \%$. The awareness of core values in the countries of target language rose which led to decrease from $6 \%$ of unsure students to $1 \%$.

During our study we came to the conclusion that students in the focus group are aware of intercultural competence and recognize its importance for international communication. Nevertheless, there is also a misunderstanding in the proper definition of the term and necessity of working with students`awareness in this field. The results we obtained after conducting the survey and analysing its results could be used for the enhancing English language curriculum in the universities. With the use of information gathered we were able to create an effective set of exercises which helps to work on the points that were proven to be weaknesses of the future economists.

\section{Acknowledgements}

The work is performed according to the Russian Government Program of Competitive Growth of Kazan Federal University.

\section{References}

Albina R. Abdrafikova, Rimma M. Akhmadullina \& Tatiana S. Pimenova. Professional Adaptation of Students as Future Teachers Using Case Study Technology / Albina R. Abdrafikova, Rimma M. Akhmadullina \& Tatiana S. Pimenova // Research Journal of Applied Sciences. - 2015. - Volume 10 (Issue 10). - PP. 643-647. - ISSN: 1815-932X

Chiu, Chi-Yue, Lonner, W. J, Matsumoto, D., Ward, C., CrossCultural Competence: Theory, Research, 
and Application. Journal of CrossCultural Psychology, vol. 44, issue 6, pp 843-848, 2013.

Deardorff D.K., Identification and assessment of intercultural competence as a student outcome of internationalization. Journal Studies in International Education, vol. 10, issue 3, pp 241-266, 2006.

Fahrutdinova R.A, Yarmakeev I.E, Fakhrutdinov R.R., The formation of students` foreign language communicative competence during the learning process of the English language through interactive learning technologies (The study on the basis of Kazan Federal University)//English Language Teaching. - 2014. - Vol.7, Is.12. - P.3646.

Federal state educational standard of higher professional education for the training (qualification: bachelor of economics) [Electronic resource] / access Mode: http://mon.gov.ru/dok/. 23.03.15 checked.

Gorelova J.N., Advertising language as a means of forming students' cross- cultural competence, Procedia - Social

and Behavioral Science, vol.152, pp.668-672, 2014.

Kramsch C., The language teacher as gobetween. Utbildning \& Demokrati, vol. 13(3), pp 37-60, 2004.

L.Salekhova, K.Grigorieva Russia country report: multicultural experience in education //11th international technology, education and development conference, Valencia, Spain, 6-8 march, 2017, pp. 0435-0441.

Sinicrope C., Norris J., Watanabe Y., Understanding and assessing intercultural competence: A summary of theory, research, and practice, 2012 The work is performed according to the Russian Government Program of Competitive Growth of Kazan Federal University.

Yarmakeev Iskander E., Abdrafikova Albina R., Pimenova Tatiana S., Eshenko Ekaterina Yu. Students' tolerance formation in multiethnic educational environments in efl class // modern journal of language teaching methods. - 2016. - vol. 1. - p. 170-177 